\title{
Manajemen Kepala Sekolah dalam Pengelolaan Anggaran Pendapatan dan Belanja Sekolah SMA Negeri 10 Tanjung Jabung Timur
}

\author{
Maria Hastuti, Martinis Yamin \& Lukman Hakim \\ Pascasarjana UIN Sulthan Thaha Saifuddin Jambi \\ E-mail: mariahastuti@gmail.com
}

\begin{abstract}
This study aims to examine the management of the Principal towards the school's income and expenditure budget (APBS) at Public High School or SMAN 10 East Tanjung Jabung, Jambi. The research was motivated by 1) APBS planning carried out by the Principal was only formulated by school managerial decision makers, was not discussed openly with all existing human resources, 2) there was still limited training by the Principal regarding the preparation of the APBS, 3) Principals had difficulty adjusting the APBS plan with needs, and 4) the assessment of the implementation of the APBS is not effective. This research uses qualitative methods that are based on the philosophy of postpositivism. Data is obtained through participation observation, interviews, and documentation. Based on the research, it is known that the sources and budget allocations are still limited. there are still problems with the process, namely: a) Still difficult for budget users to specify budget requirements, $b$ ) The ability of administrative personnel to manage BOS is limited, c) school budget allocation as a source of school development is still not in accordance with the real needs of schools and d) Limitations of school principals carry out continuous monitoring. Planning activities are still not detailed, the implementation has been carried out in accordance with the planning, and the APBS evaluation has been carried out effectively.
\end{abstract}

Keywords: management; school principal; school budget and expenditure.

Abstrak: Penelitian ini bertujuan untuk mengkaji manajemen Kepala Sekolah terhadap anggaran pendapatan dan belanja sekolah (APBS) di SMAN 10 Tanjung Jabung Timur. Penelitian dilatarbelakangi oleh 1)Perencanaan APBS yang dilakukan Kepala Sekolah hanya dirumuskan oleh para pengambil keputusan manajerial sekolah, tidak dibicarakan secara terbuka dengan seluruh SDM yang ada, 2)masih terbatasnya pelatihan Kepala Sekolah tentang penyusunan APBS, 3)Kepala Sekolah kesulitan menyesuaikan rencana APBS dengan kebutuhan, dan 4)penilaian pelaksanaan APBS tidak efektif. Penelitian mengggunakan metode kualitatif dengan pendekatan post-positivisme. Data didapatkan melalui observasi partisipasi, wawancara, dan dokumentasi. Berdasarkan penelitian yang dilakukan diketahui bahwa sumber dan alokasi anggaran sekolah masih terbatas. Proses penggunaan anggaran masih ada permasalahan yaitu: a) Masih kesulitannya pengguna anggaran merincikan kebutuhan anggaran; b) Kemampuan tenaga administrasi dalam mengelola BOS masih terbatas; c) alokasi anggaran sekolah sebagai sumber pembinaan sekolah masih belum sesuai dengan kebutuhan riil sekolah; dan d) Keterbatasan kepala sekolah melakukan pengawasan secara terus menerus. Kegiatan perencanaan masih belum rinci, pelaksanaan sudah coba dilakukan sesuai dengan perencanaan, dan evaluasi APBS telah dilakukan secara efektif.

Kata-kata kunci: manajemen; kepala sekolah; APBS. 


\section{Pendahuluan}

Kepala sekolah memiliki otoritas utama untuk menyiapkan langkah-langkah penting mulai dari tahap perencanaan, pelaksanaan, pengawasan, evaluasi, dan pelaporan terhadap proses pembelajaran yang berlangsung di sekolah. Oleh karena itu, penguasaan kecakapan kepemimpinan kepala sekolah menjadi hal yang sangat penting. Kecapakan kepemimpinan tidak lagi diukur dari keterampilan menyelenggarakan kegiatan operasional, melainkan dari kemahiran dan kemampuannya menggerakkan orang lain dalam organisasi. Usaha mewujudkan capaian tingkat tinggi dari sebuah sekolah, bukanlah pekerjaan mudah. Untuk memenuhi capaian tersebut, ada beberapa hal yang harus menjadi perhatian kepala sekolah, diantaranya: penetapan kriteria yang ketat untuk setiap perilaku mengajar guru; penetapan kriteria yang ketat untuk setiap perilaku belajar siswa; penetapan kriteria yang ketat untuk setiap kegiatan interaksi antara guru dan siswa; penyediaan buku-buku pembelajaran dan buku pelengkap; pemetaan kegiatan kurikuler dan ekstrakurikuler yang mendukung program inti sekolah; evaluasi keefektifan pembelajaran secara kontinyu; pelembagaan programprogram yang bersifat kompetitif; pelibatan orang tua atau wali siswa dalam mengontrol perilaku belajar di rumah; pengembangan budaya belajar; mendatangkan nara sumber sebagai kelompok teladan, dan kegiatan lain yang relevan. ${ }^{1}$

Allah berfirman dalam Al-Qur'an yang artinya Artinya: "Dan Kami jadikan di antara mereka itu pemimpin-pemimpin yang memberi petunjuk dengan perintah Kami ketika mereka sabar. Dan adalah mereka meyakini ayat-ayat Kami" (Q.S. 32: 24). ${ }^{2}$

Berdasarkan ayat tersebut, terlihat bahwa para pemimpin berperan penting dalam memberi petunjuk dengan kesabaran. Kepala sekolah/madrasah mempunyai peranan yang sangat berpengaruh di lingkungan sekolah yang menjadi tanggung jawabnya. Tugas kepala sekolah/madrasah selaku pemimpin adalah membantu para guru mengembangkan potensi mereka secara maksimal dan menciptakan lingkungan sekolah yang kondusif yang mendorong para guru, staf, dan peserta didik untuk mempermudah kehendak, pikiran, dan tindakan dalam kegiatan kerja sama yang efektif bagi tercapainya tujuan-tujuan sekolah. ${ }^{3}$

Baik atau buruknya sebuah sekolah lebih banyak ditentukan oleh kewenangan kepala sekolah sebagai pengelolanya. Oleh sebab itu, seorang kepala sekolah setidaknya harus menguasai bekal kemampuan untuk 1) menyusun program kegiatan sekolah; 2) menetapkan prosedur mekanisme kerja; melaksanakan monitoring, evaluasi, supervisi, dan membuat laporan kegiatan sekolah; serta 3) meningkatkan dan memantapkan disiplin guru dan siswa ${ }^{4}$ yang terangkum dalam kebijakan pendidikan. Hal tersebut dilakukan sebagai bagian dari kebijakan pendidikan. Kebijakan pendidikan yang efektif ditentukan secara bersama oleh para pengambil keputusan manajerial, dan dibicarakan secara

\footnotetext{
${ }^{1}$ Sudarwan Danim, Otonomi Manajemen Sekolah (Bandung: Alfabeta, 2010), hal. 149.

${ }^{2}$ Anonim, Al-Qur'an dan Terjemahnya (Jakarta: Departemen Agama RI, 2007), hal. 663.

${ }^{3}$ Sudarwan Danin, Otonomi... Op. Cit., hal. 64.

${ }^{4}$ Husaini Usman, Manajemen; Teori, Praktek dan Riset Pendidikan (Jakarta: Bumi Aksara,
} 2013), hal. 314 . 
terbuka dengan seluruh aparat/sumber daya manusia yang terlibat dalam lembaga/perusahaan itu.

Selama ini ada kesan bahwa keuangan adalah segalanya dalam memajukan sesuatu lembaga pendidikan. Tanpa dukungan finasial yang cukup, manajer lembaga pendidikan seakan tidak bisa berbuat banyak dalam upaya memajukan lembaga pendidikan yang dipimpinnya. Sebab, mereka berpikir semua upaya memajukan senantiasa harus dimodali uang. Upaya memajukan komponenkomponen pendidikan tanpa disertai dukungan uang seakan pasti mandek di tengah jalan. Setidaknya ada dua hal yang menyebabkan timbulnya perhatian yang besar pada keuangan, yaitu: pertama, keuangan termasuk kunci penentu kelangsungan dan kemajuan lembaga pendidikan. Kenyataan ini mengandung konsekuensi bahwa program-program pembaharuan atau pengembangan pendidikan bisa gagal dan berantakan manakala tidak didukung oleh keuangan yang memadai. Kedua, lazimnya uang dalam jumlah besar sulit sekali didapat khususnya bagi lembaga pendidikan swasta yang baru berdiri ${ }^{5}$.

Anggaran pendapatan dan belanja sekolah adalah rencana yang diformulasikan dalam bentuk rupiah untuk jangka waktu tertentu (periode), serta lokasi sumber-sumber kepada setiap bagian aktivitas sekolah. Anggaran pendapatan dan belanja sekolah memiliki peran penting di dalam perencanaan, pengendalian dan evaluasi aktivitas penting yang dilakukan di madrasah ${ }^{6}$. Keuangan sekolah merupakan salah satu sumber daya yang secara langsung menunjang efektivitas dan efisiensi pengelolaan pendidikan. Hal tersebut lebih terasa lagi dalam implementasi manajemen berbasis sekolah, yang menuntut kemampuan sekolah untuk merencanakan, melaksanakan, dan mengevaluasi serta mempertanggungjawabkan pengelolaan dana secara transparan kepada masyarakat dan pemerintah. Sumber keuangan dan pembiayaan pada suatu sekolah secara garis besar dapat dikelompokkan atas tiga sumber, yaitu: 1) pemerintah, baik pemerintah pusat, daerah maupun kedua-duanya yang bersifat umum atau khusus dan diperuntukkan bagi kepentingan pendidikan; 2) orang tua atau peserta didik; 3) masyarakat baik mengikat maupun tidak mengikat ${ }^{7}$.

Berdasarkan observasi uang dilakukan di SMAN 10 Tanjung jabur Timur terdapat beberapa permasalahan dalam pengelolaan APBS, yaitu

a. perencanaan APBS yang dilakukan kepala sekolah hanya dirumuskan oleh para pengambil keputusan manajerial sekolah, tidak dibicarakan secara terbuka dengan seluruh aparat/sumber daya manusia yang terlibat dalam lembaga sekolah tersebut. ${ }^{8}$

b. pengelolaan pelaksanaan APBS yang dilakukan kepala sekolah dengan memberikan jabatan kepada masing-masing staf pengelola anggaran untuk bekerja sesuai dengan tugas pokok dan fungsinya dalam struktur pengelolaan anggaran, meskipun staf yang bekerja belum cakap di bidang administratif.

\footnotetext{
${ }^{5}$ Mujamil Qomar, Manajemen Pendidikan Islam (Jakarta: Erlangga, 2007), hal. 163.

${ }^{6}$ Muhaimin, dkk., Manajemen Pendidikan: Aplikasinya dalam Penyusunan Rencana Pengembangan Sekolah/Madrasah (Jakarta: Kencana, 2011), hal. 357.

${ }^{7}$ E. Mulyasa, Manajemen Berbasis Sekolah (Bandung: Remaja Rosdakarya, 2007), hal. 47, 48.

8 Wawancara, 18 Juli 2016
} 
c. Kepala sekolah masih kesulitan menyesuaikan dengan kebutuhan sekolah dan menempaikan sumber-sumber dana pada pos-pos jangka pendek, jangka menengah dan jangka panjang sekolah. Misalnya minimnya anggaraan untuk pembinaan guru, pembinaan ekstrakurikuler dan pemeliharaan sarana dan prasarana. $^{9}$

d. penilaian pelaksanaan APBS ada selama ini terhadap pola perencananaan dan pelaksanaan belanja sekolah tidak efektif, karena perbaikan hanya dilakukan kepala sekolah saja, tanpa ada masukan dari guru maupun wakil kepala sekolah. Pihak manajerial belum memiliki tingkat keterbukaan dan akuntabilitas yang tinggi, khususnya tentang asal uang diperoleh dan penggunaannya. ${ }^{10}$

Berdasarkan permasalahan tersebut maka peneliti berfokus pada Manajemen Kepala Sekolah terhadap pengelolaan Anggran Pendapatan Dan Belanja pada Sekolah Menengah Atas Negeri 10 Tanjung Jabung Timur Ta. 2016/2017. Metode yang digunakan dalam penelitian adalah metode kualitatif dengan filsafat postpositivisme. Data primer dikumpulkan dengan observasi partisipasi, wawancara, dan dokumentasi. Data sekunder diperoleh dari dokumen berupa arsip, dokumen resmi, brosur, jurnal, buku panduan, struktur organisasi, dan lain-lain. Analisis data menggunakan model analisis data mengalir. ${ }^{11}$

\section{Kemampuan Kepala Sekolah Mengelola APBS}

Berdasarkan penelitian yang telah dilakukan diketahui bahwa terdapat beberapa hal penting terkait manajemen kepala sekolah dalam perencanaan anggaran pendapatan dan belanja sekolah, terutama Kepala Sekolah belum mampu mengatur anggaran pendapatan dan belanja di SMAN 10 Tanjung Jabung Timur yang disebabkan beberapa seperti sumber pendapatan terbatas, sumber daya manusia pengelola APBS belum tersedia.

\subsection{Sumber Pendapatan Sekolah Terbatas}

Berdasarkan pada hasil wawancara peneliti dengan beberapa guru, murid, masyarakat dan anggota anggaran sekolah, diketahui bahwa guru tak mengetahui persis kondisi keuangan sekolah, namun menduga bahwa pembiayaan pendidikan di sekolah ini sangat jauh dari cukup. Hal itu terlihat dari ruang kelas yang masih banyak kekurangan bangku, gaji guru honor sering terlambat, laboratorium belum maksimal difungsikan, uang untuk pelatihan guru masih kurang, dan lain-lain. ${ }^{12}$

Komentar yang dikemukakan oleh salah seorang guru sekolah tersebut sejalan dengan pengamatan yang dilakukan oleh peneliti, di beberapa kelas terdapat bangku-bangku dan meja yang sudah tidak layak pakai, laboratorium bahasa tidak ada, alat-alat praktek IPA yang tidak lengkap, serta ruangan komputer tidak ada. ${ }^{13}$ Hal tersebut menunjukan bahwa kondisi dan keadaan pembiayaan pendidikan di SMAN 10 Tanjung Jabung Timur tidak mencukupi untuk sebatas biaya operasional pembiayaan pendidikan standar, apalagi jika

${ }^{9}$ Wawancara, 19 Juli 2016

10Wawancara, 19 Juli 2016

11Matthew B. Miles dan Michael A. Huberman, Analisis Data Kualitatif: Buku Sumber Tentang Metode-Metode Baru Terj. Tjetjep Rohedi Rohidi (Jakarta: UI Press, 2007), hal. 16-20.

12Wawancara, 3 Oktober 2016

13Wawancara, 3 Oktober 2016 
dikaitkan dengan peningkatan mutu pendidikan, maka pembiayaan pendidikan di SMAN 10 Tanjung Jabung Timur sangat tidak mencukupi. Banyaknya fasilitas dan sarana yang kurang dan rusak menunjukkan bahwa pembiayaan pendidikan di SMAN 10 Tanjung Jabung Timur mengalami masalah, dan jelas menunjukkan kekurangan pembiayaan pendidikan di SMAN 10 Tanjung Jabung Timur jika dikaitkan dengan tujuan sekolah yang bermutu, sehingga sekolah ini sangat bertegantungan kepada anggaran sekolah dalam membantu pembiayaan pendidikan di SMAN 10 Tanjung Jabung Timur, khususnya dalam membayar gaji bulanan dari guru-guru honorer dan untuk melengkapi sarana dan prasarana lainnya. ZN, selaku Ketua Komite di SMAN 10 Tanjung Jabung Timur mengatakan bahwa pembiayaan pendidikan di sekolah ini bersumber dari pemerintah pusat melalui anggaran sekolah yang digunakan untuk biaya operasional sekolah termasuk gaji guru dan pegawai SMAN 10 Tanjung Jabung Timur. ${ }^{14}$

ZN, selaku ketua komite sekolah di SMAN 10 Tanjung Jabung Timur mengemukakan bahwa dalam upaya membantu pembiayaan pendidikan di SMAN 10 Tanjung Jabung Timur tidak dapat kami lakukan secara maksimal melalui pemungutan uang komite perbulan dan pertahun yang dibebankan kepada orang tua siswa, memungut bayaran uang pembangunan kepada siswa-siswi dan lain sebagainya. ${ }^{15}$ Setiap unit kerja selalu berhubungan dengan masalah keuangan. Tidak terkecuali dengan SMAN 10 Tanjung Jabung Timur. Kurangnya dana dalam pelaksanaan pendidikan dan pembelajaran di SMAN 10 Tanjung Jabung Timur membuat pengadaan sarana pembelajaran belum terpenuhi secara memadai. Wawancara dengan TH, kepala SMAN 10 Tanjung Jabung Timur yang mengatakan bahwa sampai saat ini SMAN 10 Tanjung Jabung Timur masih mengalami kendala dalam penyediaan dana yang bisa digunakan bagi pengadaan sarana pembelajaran. Komite sekolah dan pihak sekolah telah mencoba berbagai upaya agar menemukan solusi agar sarana ini bisa tersedia melalui dukungan dana yang memadai. ${ }^{16}$

Sampai saat ini, permasalahan dana belum teratasi dengan baik oleh pihak sekolah. Dana yang masih terbatas yang dimiliki pihak sekolah menyebabkan upaya peningkatan mutu pendidikan juga mengalami kendala. ${ }^{17}$ Wawancara ini menjelaskan bahwa SMAN 10 Tanjung Jabung Timur dalam pelaksanaan pendidikan dan pembelajaran sehari-hari khususnya untuk kelengkapan sarana pembelajaran masih kekurangan karena keterbatasan dana untuk melengkapi fasilitas yang ada.

Pembiayaan pendidikan di SMAN 10 Tanjung Jabung Timur yang bersumber dari pemerintah pusat seperti anggaran sekolah, merupakan bantuan pembiayaan yang sangat besar dan seharusnya pembiayaan tersebut dapat atau mampu sekedar memenuhi kebutuhan standar pembiayaan pendidikan. Sesna Herawati, bendahara di sekolah tersebut mengatakan bahwa kondisi keuangan di SMAN 10 Tanjung Jabung Timur bisa dikatakan cukup, bisa juga dikatakan kurang. Dikatakan cukup karena selama ini berjalan lancar-lancar saja, sedangkan dikatakan kurang, jika dilihat kondisi lokal-lokal yang masih banyak kurang

\footnotetext{
${ }^{14}$ Wawancara, 3 Oktober 2016

15Wawancara, 3 Oktober 2016

16Wawancara, 3 Oktober 2016

${ }^{17}$ Wawancara, 6 Oktober 2016
} 
bangku, kesejahteraan guru khususnya guru honor tidak diperhatikan, labor-labor yang tidak ada, komputer tidak sesuai dengan jumlah murid dan lain-lain. ${ }^{18}$ Salah seorang guru yang berstatus honorer mengatakan bahwa sebagai guru SMAN 10 Tanjung Jabung Timur tidak tahu masalah pembiayaan pendidikan di sekolah, karena selama ini tidak ada laporan ataupun pembahasan masalah pembiayaan pendidikan dalam rapat guru dan pegawai. ${ }^{19}$

\subsection{Kualitas SDM Pengelola APBS}

Berdasarkan observasi dan wawancara dilakukan diketahui bahwa pegawai administrasi selalu berhati-hati dalam penginputan data-data atau dokumendokumen sekolah, hanya saja penyimpanan arsip-arsip di simpan dalam bentuk soft copy saja dan hanya menggandakan dalam flasdish, sebaiknya pegawai administrasi selain mengarsipkan dalam bentuk soft copy juga harus diprint out sebagai arsip yang baku, sebab dalam bentuk soft copy dikhawatirkan rusak atau hilang, sehingga akan merugikan lembaga sekolah itu sendiri.

\subsection{Administrasi Anggaran Belum Tertib}

Berdasarkan pengamatan dan wawancara, diketahui bahwa Kepala sekolah sudah mengawasi penanganan masalah administrasi secara kontinu. Walaupun kurang terjadwal, Kepala sekolah juga telah melakukan evaluasi dan menemukan bahwa kelemahan pegawai administrasi adalah bekerja kurang mengacu pada petunjuk teknis pengurusan anggaran sekolah 20 .

\subsection{Belanja Sekolah Tidak Tersusun Rinci}

Kepala SMAN 10 Tanjung Jabung Timur adalah orang yang memiliki kemampuan untuk mengelola sumber daya manusia, memberikan inspirasi untuk memajukan dan mencapai tujuan melalui kegiatan-kegiatan administrasi. Dalam konteks pengembangan, SMAN 10 Tanjung Jabung Timur merupakan lembaga yang bersifat kompleks dan unik, karena sebagai sebuah organisasi di dalamnya terdapat berbagai dimensi satu sama lainnya saling berkaitan dan memiliki ciri-ciri tertentu sebagai sifat yang unik yang tidak memiliki oleh organisasi lainnya, yaitu terjadi proses pembelajaran dan tempat terselenggaranya pemberdayaan kehidupan manusia.

Berdasarkan wawancara dengan Sesna Herawati (pegawai administrasi), diketahui bahwa dalam menyusun rencana keuangan kendala yang dihadapi adalah para pengguna anggararan seperti OSIS, Pramuka, PMR, PKS, Ekstrakurikuler, Olimpiade, Kurikulum, Kesiswaan, Laboratorium, Perpustakaan, dan Sarana Prasarana, belum dapat merinci kegiatan dan estimasi biaya yang dibutuhkan secara komprehensif ${ }^{21}$. Pelaksanaan kegiatan administrasi, pegawai administrasi sangat berperan penting dan bertanggungjawab dalam membantu merincikan kebutuhan penggunaan anggaran anggaran sekolah di sekolah agar lebih mudah dan lebih terarah.

18Wawancara, 6 Oktober 2016

${ }^{19}$ Wawancara, 6 Oktober 2016

${ }^{20}$ Observasi, 17 Oktober 2016

${ }^{21}$ Wawancara, 17 Oktober 2016 


\section{Perencanaan APBS oleh Kepala SMAN 10 Tanjung Jabung Timur}

Kepala sekolah mempunyai tugas dan tanggung jawab mengelola APBS. Sebagai manajer, kepala sekolah mempunyai tugas menyusun perencanaan, mengorganisasikan kegiatan, mengarahkan, mengkoordinir dan melaksanakan pengawasan, melakukan evaluasi terhadap kegiatan APBS, menentukan kebijaksanaan, mengadakan rapat, mengambil keputusan serta mengatur proses pembelajaran untuk mencapai tujuan pengelolaan APBS. Sedangkan sebagai pemimpin, Kepala Sekolah harus mampu memberdayakan segala sumber daya sekolah, termasuk tanggung jawabnya dalam pengelolaan APBS di SMAN 10 Tanjung Jabung Timur. Kemandirian kepala sekolah diperlukan terutama untuk memobilisasi sumber daya sekolah seperti keuangan sekolah dalam kaitannya dengan perencanaan, pengorganisasian, penggerakan dan pengawasan bagi program sekolah.

Perencanaan adalah bagian yang cukup penting dari sebuah pengelolaan. Orang bijak menyampaikan nasehat bahwa jika gagal membuat perencanaan berarti telah merencakanan kegagalan. Kaitannya dengan pengelolaan anggaran sekolah di SMAN 10 Tanjung Jabung Timur, kepala sekolah juga telah membuat rencana sebagai langkah awal pengelolaan anggaran sekolah. Perencanaan pengelolaan anggaran sekolah dimulai dengan memperkirakan anggaran sekolah yang akan diterima, kemudian disusul dengan perkiraan (rencana) belanja berbagai kegiatan/kebutuhan yang akan dibiayai dari anggaran sekolah tersebut. Kegiatan inilah yang dikenal dengan sebutan Rencana Anggaran Pendapatan dan Belanja Sekolah (RAPBS). Pada tahun ajaran 2014/ 015, anggaran sekolah yang diterima oleh SMAN 10 Tanjung Jabung Timur sebesar Rp.304.708.000.22

Anggaran sekolah tersebut kemudian kepala sekolah membuat rencana pendapatan anggaran sekolah sesuai dengan aturan yang telah ditetapkan oleh pemerintah. Berikut ini rencana pendapatan SMAN 10 Tanjung Jabung Timur:

Tabel 1

Rencana Pendapatan SMAN 10 Tanjung Jabung Timur ${ }^{23}$

Komponen Jumlah Dana (Rp)

Bantuan Operasional Sekolah (BOS)

a. BOS Pusat Rp. 226.100 .000

b. BOS Kabupaten Rp. 78.608 .000

Jumlah Penerimaan/Pendapatan Rp.304,708.000

Rencana tersebut dimaksudkan agar kesalahan dan penyalahgunaan anggaran sekolah dapat diminimalisasi. Berbagai rencana pembiayaan dengan anggaran sekolah harus sesuai dengan aturan yang telah ditetapkan oleh pemerintah. Hal ini dinyatakan oleh kepala sekolah bahwa sekolah penerima anggaran sekolah harus mengikuti segala ketentuan yang telah ditetapkan oleh pemerintah. Berikut ini rencana belanja di SMAN 10 Tanjung Jabung Timur:

${ }^{22}$ Wawancara, 5 September 2016

${ }^{23}$ Dokumentasi SMAN 10 Tanjung Jabung Timur Tahun 2016 
Tabel 2

Rencana Belanja pada SMAN 10 Tanjung Jabung Timur ${ }^{24}$

\begin{tabular}{|c|c|c|}
\hline No & Uraian & Jumlah \\
\hline 1 & Pengembangan Kompetensi Lulusan & Rp. 10.088 .000 \\
\hline 2 & Pengembangan Standar Isi & Rp. 11.738 .000 \\
\hline 3 & Pengembangan Standar Proses & Rp. 41.179 .000 \\
\hline 4 & $\begin{array}{l}\text { Pengembangan Standar Pendidik dan } \\
\text { Tenaga Kependidikan }\end{array}$ & Rp. 12.350 .000 \\
\hline 5 & $\begin{array}{l}\text { Pengembangan Standar Sarana dan } \\
\text { Prasarana Sekolah }\end{array}$ & Rp. 110.913 .000 \\
\hline 6 & Pengembangan Standar Pengelolaan & Rp. 18.496 .000 \\
\hline 7 & Pengembangan Standar Pembiayaan & Rp. 74.924 .000 \\
\hline 8 & $\begin{array}{l}\text { Pengembangan dan Impelementasi Sistem } \\
\text { Penilaian }\end{array}$ & Rp. 25.020.000 \\
\hline
\end{tabular}
Jumlah Pengeluaran/Belanja

Rp. $304,708,000$

Sesuai dengan ketetapan yang telah ditentukan oleh pemerintah, bahwa penggunaan anggaran sekolah di SMAN 10 Tanjung Jabung Timur telah diupayakan sesuai dengan ketentuan dan diupayakan untuk tidak melanggar aturan dan poin-poin yang ditetapkan oleh pemerintah. Oleh karena itu pihak pengelola sekolah dalam hal ini adalah kepala sekolah membuat rencana-rencana yang sesuai dengan ketentuan-ketentuan tersebut.

Berdasarkan informasi dari kepala sekolah saat wawancara, diketahui bahwa RAPBS SMAN 10 Tanjung Jabung Timur berkaitan dengan BOS, jika diperhatikan dengan seksama, maka rencana atau anggaran yang disusun dengan baik. Namun sebaiknya kepala sekolah lebih merinci lagi dengan daftar kebutuhan per item, sehingga anggaran yang ada akan lebih tepat sasaran.

\section{Pengelolaan APBS oleh Kepala SMAN 10 Tanjung Jabung Timur}

Pengelolaan keuangan sekolah seperti anggaran sekolah tidak dapat dilakukan oleh sembarangan orang, melainkan harus dikelola secara teroganisir. Untuk itu diperlukan organisasi pengelola yang baik. Organisasi pengelola anggaran sekolah disekolah dipimpin langsung oleh kepala sekolah, diawasi oleh komite. Organisasi terdiri dari

1. Kepala sekolah menunjuk guru/bendahara sekolah yang bertanggungjawab dalam mengelola anggaran sekolah ditingkat sekolah.

2. Komite sekolah memantau dan mengawasi pelaksanaan penggunaan anggaran sekolah yang dilakukan oleh pihak sekolah

3. Bendahara menyimpan dan membayar ke pengguna atas perintah kepala sekolah. Dengan demikian maka, bendahara tidak dapat mengeluarkan dana tanpa sepengatahuan kepala sekolah. Misalnya jika ada sebuah kegiatan yang seharusnya didanai dengan anggaran sekolah, maka panitia tidak bisa mengajukan dana langsung kepada bendahara, melainkan harus diajukan kepada kepala sekolah dan kepala sekolah memberikan surat perintah bayar

${ }^{24}$ Dokumentasi SMAN 10 Tanjung Jabung Timur Tahun 2016 
kepada bendahara. Dengan demikian setiap pengeluaran anggaran sekolah atas sepengetahuan kepala sekolah.

Pengelolaan anggaran sekolah, sekolah sebagai penerima anggaran sekolah memiliki tugas dan tanggung jawab yang tidak mudah. Sesuai dengan aturan Depdiknas, maka tugas dan tanggungjawab sekolah adalah sebagai berikut:

1. Mengelola anggaran sekolah secara bertanggungjawab dan transparan

2. Bertanggungjawab terhadap penyimpangan penggunaan dana di sekolah

3. Memberikan pelayanan dan penanganan pengaduan masyarakat.

4. Melaporkan penggunaan anggaran sekolah kepada Tim PKPS BBM Kab / Kota.

Pengelolaan keuangan sekolah perlu didukung oleh Kepala Sekolah yang mandiri dan profesional dengan kemampuan manajemen serta kepemimpinan yang tangguh, agar mampu mengambil keputusan dan prakarsa untuk meningkatkan pengelolaan keuangan sekolah. Pengelolaan keuangan dapat dilihat dari beberapa aktivitas berikut.

1. Anggaran untuk Siswa Kurang Mampu

Kepala sekolah menyatakan bahwa bagi siswa Sejahtera I dan II ada bantuan khusus, yaitu dana cash yang bersumber dari anggaran sekolah, ini dimaksudkan agar mereka bisa menggunakan untuk kebutuhan pribadi yang berkaitan dengan kegiatan pendidikan, mulai dari buku, pena, baju sekolah, transportasi dan sebagainya. Ada diantara siswa miskin disekolah ini yang naik angkot bahkan ojek yang biayanya tentu relatif lebih mahal. ${ }^{25}$ Pemberian beasiswa terhadap para siswa yang dikategorikan miskin, juga dibenarkan oleh salah seorang siswa yang telah menerima beasiswa tersebut.

2. Anggaran untuk Kegiatan Kesiswaan

Di SMAN 10 Tanjung Jabung Timur, kegiatan kesiswaannya cukup beragam, diantaranya OSIS, Pramuka, PMR serta kegiatan olah raga. Kegiatan-kegiatan tersebut dikelola dibawah koordinasi wakil kepala sekolah bidang kesiswaan. Kemudian perkegiatan dipimpin oleh seorang pembina, hal ini dimaksudkan agar pelaksanaan setiap kegiatan dapat berjalan dengan lancar. Dalam rangka memperlancar kegiatan kesiswaan tersebut maka sekolah menjadikannya sebagai pertimbangan untuk mengalokasikan dana. Keberagaman kegiatan kesiswaan tentu saja menambah jumlah anggaran pendidikan bidang tersebut. Oleh karena itu, dana yang dialokasinya pada RAPBS untuk kegitan kesiswaan cukup besar yaitu mencapai Rp. 24.762.000 setahun sejak Januari s.d Desember 2016. ${ }^{26}$

3. Pembayaran Honorarium Guru dan Tenaga Kependidikan Honorer Adapun jumlah tenaga honorer di SMAN 10 Tanjung Jabung Timur mencapai 4 orang. Semua tenaga honorer tersebut menerima gaji dari anggaran sekolah, oleh karena itu wajarlah jika kesejahteraan bagi tenaga honorer dijadikan faktor yang turut serta dalam mempengaruhi pengelolaan anggaran sekolah. Para tenaga honorer tersbut mendapatkan gaji yang berbeda-beda, tergantung pada jenis pekerjaannya. Hal ini diungkapkan oleh kepala sekolah bahwa bahwa semua tenaga honorer kita gaji dengan BOS. Namun demikian mereka digaji berdasarkan jenis pekerjaannya. Tidak mungkin seorang guru sarjana gajinya

25Wawancara, 15 September 2016

26Dokumentasi SMAN 10 Tanjung Jabung Timur Tahun 2016 
sama dengan tukang kebun atau cleaning service yang hanya lulusan SMP. Selain itu karena anggaran sekolah cair tidak tetap, maka kasihan jika kesejahteraannya tidak kita perhatikan, walaupun kadangkala kita kesulitan menggaji mereka. ${ }^{27}$ Sedangkan wawancara dengan salah sau guru honorer memberikan informasi sebagai berikut honor saya di sini berasal dari anggaran sekolah. Buktinya kalau anggaran sekolah terlambat cair, honor saya juga sedikit agak molor. ${ }^{28}$ Jika diperhatikan pernyataan di atas dapat dimaklumi, hal ini dikarenakan operasional sekolah adalah kegiatan yang urgent dalam kegiatan pendidikan. Oleh karena itu wajar jika kepala sekolah dalam hal ini adalah kepala sekolah SMAN 10 Tanjung Jabung Timur menjadikannya sebagi faktor yang utama.

4. Pengembangan Perpustakaan dan Komputer

Kendala dana menyebabkan pihak SMAN 10 Tanjung Jabung Timur menghadapi keterbatasan dalam sarana dan prasarana meliputi kurangnya buku-buku di perpustakaan dan media ibadah. Wawancara dengan salah guru di SMAN 10 Tanjung Jabung Timur diketahui bahwa dana yang kurang memadai juga menyebabkan upaya perbaikan sarana penunjang seperti sarana dan prasarana pendidikan di SMAN 10 Tanjung Jabung Timur masih menjadi kendala. Sampai saat ini, permasalahan dana belum teratasi dengan baik oleh pihak sekolah. Dana yang masih terbatas yang dimiliki pihak sekolah menyebabkan upaya peningkatan mutu pendidikan juga mengalami kendala. ${ }^{29}$ Untuk melaksanakan proses pembelajaran yang kondusif sesuai komptensi guru, diperlukan sarana dan prasarana yang memadai seperti media pembelajaran. Guru yang profesional akan memanfaatkan sarana dan prasarana yang ada sebagai bahan pembantu dalam mengajar. Kenyataannya berdasarkan wawancara dengan guru Pendidikan Agama Islam di SMAN 10 Tanjung Jabung Timur, dijelaskan bahwa sarana dan prasarana masih kurang lengkap, sehingga guru hanya menggunakan media seadanya di sekolah. ${ }^{30}$

\section{Penilaian Pelaksanaan APBS oleh Kepala SMAN 10 Tanjung Jabung Timur}

Pengawasan anggaran sekolah menjadi agenda yang tak kalah penting. Pengawasan anggaran sekolah dapat dilakukan oleh beberapa pihak. Pertama, komite atau dewan sekolah. Komite sekolah yang terdiri dari wakil pemerintah daerah, guru, tokoh masyarakat dan wakil alumni mempunyai tanggung jawab dalam menjalankan fungsi kontrol. Komite sekolah dapat mengawasi jalannya penggunaan anggaran sekolah dari dalam. Artinya, mereka dapat memantau segala kegiatan dan penggunaan anggaran sekolah sebagai representasi sekolah itu sendiri.

Kegiatan pengawasan yang dimaksud adalah kegiatan yang bertujuan untuk mengurangi atau menghindari masalah yang berhubungan dengan

\footnotetext{
27Wawancara, 15 September 2016

28Wawancara, 17 September 2016

${ }^{29}$ Wawancara, 17 September 2016

30Wawancara, 17 September 2016
} 
penyalahgunaan wewenang, kebocoran dan pemborosan keuangan negara, pungutan liar dan bentuk penyelewengan lainnya. Pengawasan APBS dari dana BOS meliputi pengawasan melekat (Waskat), pengawasan fungsional dan pengawasan masyarakat.

1. Pengawasan Melekat. Pengawasan melekat adalah pengawasan yang dilakukan oleh pimpinan masing-masing instansi kepada bawahannya, baik di tingkat pusat, Provinsi, kab/kota maupun sekolah. Prioritas utama dalam program BOS adalah pengawasan yang dilakukan oleh Kantor Wilyah Kementerian Pendidikan Kabupaten/Kota kepada sekolah.

2. Pengawasan Fungsional Internal. Instansi pengawas fungsional yang melakukan pengawasan program BOS secara internal adalah Inspektorat Jenderal Kementerian Pendidikan dan Kebudayaan RI. Instansi tersebut bertanggungjawab untuk melakukan audit sesuai dengan kebutuhan lembaga tersebut atau permintaan instansi yang akan diaudit.

3. Pengawasan Eksternal. Instansi pengawas eksternal yang melakukan pengawasan program BOS adalah Badan Pengawas Keuangan dan Pembangunan (BPKP). Instansi ini bertanggung jawab untuk melakukan audit sesuai dengan kebutuhan lembaga tersebut atau permintaan instansi yang akan diaudit.

4. Pemeriksaan. Badan Pemeriksa Keuangan (BPK) sesuai dengan kewenangannya dapat melakukan pemeriksaan terhadap program BOS

5. Pengawasan Masyarakat. Dalam rangka transparansi pelaksanaan program BOS, program ini juga dapat diawasi oleh unsur masyarakat dan unit-unit pengaduan masyarakat yang terdapat di sekolah, Kabupaten/Kota, Provinsi dan Pusat. Lembaga tersebut melakukan pengawasan dalam rangka memotret pelaksanaan program BOS di sekolah, namun tidak melakukan audit. Apabila terdapat indikasi penyimpangan dalam pengelolaan BOS, agar segera dilaporkan kepada instansi pengawas fungsional atau lembaga berwenang lainnya. ${ }^{31}$

Pengawasan memiliki peran yang sangat penting dalam dunia menajemen. Tanpa adanya pengawasan maka proses manajemen tidak akan berjalan secara maksimal, bahkan akan berjalan secara pincang. Hal ini terjadi karena masingmasing anggota atau fungsi menajemen akan berjalan secara sendiri-sendiri. Tidak hanya itu, bisa jadi beberapa fungsi manajmen mungkin tidak berjalan sama sekali. Menurut TH, kepala SMAN 10 Tanjung Jabung Timur yang mengatakan sebagai upaya untuk meningkatkan pengelolaan APBS adalah melakukan pengawasan terhadap kerja pengelolaan keuangan sekolah yang dilakukan setiap 4 kali dalam setahun secara internal atau triwulan, sedangkan secara ekstrenal dilakukan oleh oleh 1 kali dalam 1 tahun. ${ }^{32}$

Wawancara dengan kepala tata usaha di SMAN 10 Tanjung Jabung Timur dikatakan bahwa kepala sekolah selalu melibatkan tenaga administrasi dalam perencanaan dalam rangka pengelolaan keuangan sekolah yang berkualitas. Kepala SMAN 10 Tanjung Jabung Timur melakukan pengawasan tahunan disusun dengan cakupan kegiatan pengawasan pada pelaksanaan pengelolaan keuangan

31Dokumentasi SMAN 10 Tanjung Jabung Timur Tahun 2016

32Wawancara, 20 September 2016 
sekolah dalam kurun waktu satu Tahun. Pengawasan tahunan disusun dengan melibatkan sejumlah pengawas dalam satu wilayah untuk setiap jenjang pendidikan. Program pengawasan semester merupakan penjabaran program pengawasan Tahunan pada masing-masing sekolah binaan selama satu semester yang disusun oleh masing-masing pengawas.

Pengawasan semester disusun oleh setiap pengawas sesuai kondisi obyektif sekolah binaannya masing-masing. Program pengawasan sekolah adalah rencana kegiatan pengawasan yang akan dilaksanakan oleh pengawas dalam kurun waktu (satu periode) tertentu. Agar dapat melaksanakan tugasnya dengan baik, pengawas sekolah harus mengawali kegiataannya degan menyusun program kerja pengawasan yang jelas, terarah, dan berkesinambungan dengan kegiatan pengawasan yang telah dilakukan pada periode sebelumnya. Dalam konteks manajemen, program kerja pengawasan sekolah mengandung makna sebagai aplikasi fungsi perencanaan dalam bidang pengawasan pengelolaan keuangan sekolah.

Wawancara dengan wakil kepala SMAN 10 Tanjung Jabung Timur yang mengatakan bahwa upaya kepala SMAN 10 Tanjung Jabung Timur terhadap pengawasan pengelolaan keuangan sekolah secara umum belum dilakukan secara optimal, di mana dalam pengawasan sebagai berikut: 1) masih terdapat pegawai yang melaksanakan pekerjaannya dengan kehendak sendiri tidak mengikuti arahan kepala sekolah, 2) terdapat pegawai yang masih tidak tahu apa yang dikerjakan pada saat itu sehingga terjadi komplain oleh guru setiap hari, 3) masih terdapat pegawai yang tidak berkomitmen dalam bekerja baik datang maupun pulang. Hal ini mengikuti kehendaknya sendiri, 4) tidak adanya realita terhadap penghargaan pada pegawai yang rajin dan berprestasi dalam bekerja, 5) SDM yang diperlukan seperti bahan-bahan, fasilitas belum memadai sehingga sering terjadi keterlambatan menyediakan apa yang dibutuhkan pada waktu itu, 6) tidak dilakukan rencana tindak lanjut, dapat berupa pemantapan, perbaikkan berkelanjutan disesuaikan dengan metode pengawasan yang dikehendaki oleh kepala sekolah. ${ }^{33}$

Peran lembaga swadaya masyarakat (LSM). LSM melalui lembaganya sendiri atau forum LSM mempunyai tugas untuk mencerdaskan masyarakat. LSM dapat berperan sebagai mitra kerja pemerintah dalam menginformasikan apa dan bagaimana seharusnya anggaran sekolah digunakan. Di SMAN 10 Tanjung Jabung Timur, pengawasan pelaksanaan pengelolaan anggaran sekolah juga dilakukan oleh komite sekolah. Komite sekolah memiliki peran yang signifikan terhadap pelaksaan pengelolaan anggaran sekolah. Keterlibatan tersebut dimulai pada saat penyusunan RAPBS hingga pelaporan pelaksaan pengelolaan anggaran sekolah.

Wawancara dengan waka kurikulum mengatakan bahwa memang pegawai administrasi yang terlibat dalam manajemen BOS yang sekarang ini baru ditugaskan, ini merupakan hasil dari evaluasi kepala sekolah, yang mana petugas administrasi yang sebelumnya kurang bertanggung jawab terhadap pekerjaannya, sehingga banyak pekerjaan yang seharusnya diselesaikan olehnya malah tertunda ${ }^{34}$. Wawancara dengan $\mathrm{TH}$, kepala SMAN 10 Tanjung Jabung Timur mengatakan bahwa pegawai administrasi sekolah ini sudah pernah kita kirimkan

33Wawancara, 20 September 2016

${ }^{34}$ Wawancara, 27 September 2016 
untuk mengikuti pelatihan-pelatihan, pernah pelatihan tentang administrasi sekolah. ${ }^{35}$ Keterangan di atas menjelaskan bahwa evaluasi telah dilakukan kepala sekolah dengan cara meroling pegawai administrasi dan mengirimkan pelatihanpelatihan administrasi dengan tujuan agar pelaksanaan administrasi di SMAN 10 Tanjung Jabung Timur lebih optimal dalam melaksanakan tugasnya sebagai administrasi.

Pembiayaan pendidikan adalah keseluruhan dana dan upaya yang diserahkan oleh masyarakat dan pemerintah untuk mendapatkan dan menciptakan pendidikan yang bermutu, dalam artian bahwa pembiayaan pendidikan merupakan kunci dari keberhasilan suatu lembaga pendidikan pada satuan pendidikan. Besarnya pembiayaan pendidikan pada salah suatu satuan pendidikan akan mempermudah satuan pendidikan tersebut untuk menjalankan program pendidikan yang telah direncanakan, namun sebaliknya kecilnya pembiayaan pendidikan pada satuan lembaga pendidikan akan memperkecil peluang dari satuan pendidikan tersebut untuk memenuhi kebutuhan pendidikan, apalagi jika dikaitkan dengan peningkatan mutu pendidikan yang sangat erat kaitannya dengan pembiayaan pendidikan.

Sementara itu dalam pandangan yang lain seperti menurut Nanang Fattah, bahwa pembiayaan pendidikan adalah jumlah biaya/uang yang dihasilkan dan dibelanjakan untuk berbagai keperluan penyelenggaraan pendidikan yang mencakup = gaji guru, peningkatan kemampuan profesional guru, pengadaan sarana ruang belajar, perbaikan ruang belajar, pengadaan perabot pembelajaran, pengadaan alat-alat belajar, pengadaan buku-buku pelajaran, alat tulis kantor, kegiatan ekstrakurikuler, kegiatan pengelolaan pendidikan, dan supervisi/pembinaan pendidikan serta ketatausahan sekolah yang semuanya diselenggarakan dalam RAPBS/tahun. ${ }^{36}$

Pembiayaan pendidikan di SMAN 10 Tanjung Jabung Timur yang merupakan sekolah harapan masyarakat Kabupaten Tanjung Jabung Timur belum mencukupi untuk sekedar memenuhi kebutuhan standar pebiayaan pendidikan, karena standar pembiayaan minimal pendidikan terdiri atas biaya investasi, biaya operasi dan biaya personal. Biaya investasi sekolah meliputi biaya penyediaan sarana dan prasarana, pengembangan sumber daya manusia dan modal kerja. Biaya operasi sekolah meliputi gaji guru dan pegawai pendidikan beserta tunjangantunjangannya, penyediaan barang atau alat habis pakai, pembayaran rekening air, daya, jasa telekomunikasi, pemeliharaan sarana dan prasarana, uang lebur, transportasi, pajak, aasuransi dan lain sebagainya. Biaya personal meliputi kebutuhan-kebutuhan person-person yang ada pada satuan pendidikan. Standar pembiayaan minimal sebagaimana di atas merupakan syarat minimal pembiayaan pendidikan yang harus dipenuhi oleh satuan lembaga pendidikan untuk menjalankan proses pendidikan pada lembaga tersebut, namun jika dikaitkan dengan peningkatan mutu pendidikan, maka tentunya masih banyak lagi ha-hal yang harus dipenuhi berkaitan masalah mutu tersebut.

Mutu pendidikan bisa dilihat dari lulusan yang berkualitas. Lulusan yang berkualitas tentu memerlukan anggaran yang memadai yang dibutuhkan

35 Wawancara, 27 September 2016

36Nanang Fattah, Op. Cit., hal. 112. 
penyelenggaraan pendidikan dan pembelajaran. Banyak sistem pendidikan menghadapi tantangan yang menakutkan dalam merekrut lulusan berkualitas tinggi sebagai guru, terutama di daerah terpencil, dan mempertahankan mereka setelah mereka dipekerjakan. Bagaimana negara seharusnya berhasil dalam memenuhi kebutuhan guru berkualitas tinggi untuk kebutuhan mereka? Bagaimana mereka menyiapkan guru untuk mata pelajaran prioritas? kompensasi yang kompetitif dan insentif lainnya, prospek karir dan keragaman, dan memberikan guru tanggung jawab sebagai profesional adalah bagian penting dari strategi untuk menarik paling berbakat mengajarkan untuk kelas paling menantang. ${ }^{37}$

Sekolah tidak dapat diakses kecuali mereka memiliki materi pendidikan yang memadai. Langkah yang tepat perlu diperkenalkan untuk meninjau persyaratan peralatan keseluruhan. Jika semua anak memiliki kesempatan yang sama untuk belajar, perhatian harus dibayar untuk kebutuhan spesifik. ${ }^{38}$

Adapun tugas kepala sekolah dalam pengelolaan APBS adalah Perencanaan anggaran; merupakan kegiatan mengidentifikasi tujuan, menentukan prioritas, menjabarkan tujuan kedalam penampilan operasional yang dapat diukur menganalisis alternatif pencapaian tujuan dengan analisis costefectiveness, membuat rekomendasi alternatif pendekatan untuk mencapai sasaran. Kemuidan Mempersiapkan anggaran; antara lain menyesuaikan kegiatan dengan mekanisme anggaran yang berlaku, bentuknya, distribusi, dan sasaran program pengajaran perlu dirumuskan dengan jelas. Melakukan inventarisasi kelengkapan peralatan, dan bahan-bahan yang telah tersedia. Mengelola pelaksanaan anggaran; antara lain mempersiapkan pembukaan, melakukan pembelajarandan membuat transasi, membuat perhitungan, mengawasi pelaksanaan sesuai dengan prosedur kerja yang berlaku, serta membuat laporan dan pertanggungjawaban keuangan. Menilai pelaksanaan anggaran; antara lain menilai pelaksanaan proses belajar mengajar, menilai bagaimana pencapaian sasaran program, serta membuat rekomendasi untuk perbaikan anggaran yang akan datang.

Anggaran dibutuhkan dalam proses pendidikan yang panjang. Pendidikan juga dapat disebut sebagai sebuah proses. Dalam hal ini, pendidikan disebut tindakan mengembangkan kecerdasan, kemampuan berpikir kritis, pemahaman sosial dan budaya, dan pemahaman diri sendiri. Pendidikan dianggap sebagai aktif dan proses dinamis yang berlangsung terus menerus selama hidup seseorang dengan cara berbagai pengalaman melalui baik dalam formal atau secara informal. ${ }^{39}$

Anggaran juga dibutuhkan untuk membina guru yang berkualitas melalui jalur pendidikan, pelatihan dan magang kerja. Pendidik guru yang baik sangat penting untuk memastikan bahwa peserta yang terlatih. Mereka harus tahu dan model metode yang berpusat pada anak, dapat menanamkan praktek ICT yang

\footnotetext{
${ }^{37}$ Andreas Schleicher, Ed., Preparing Teachers and Developing School Leaders for The 21st Century - Lessons From Around The World (New York: OECD Publishing, 2012), hal. 55.

38UNICEF, A Human Rights-Based Approach to Education (New York: United Nations Children's Fund, 2007), hal. 61.

${ }^{39}$ Chanchal Goel, et. al, Basic In Education (New Delhi: National Council of Educational Research and Training, 2014), hal. 6.
} 
baik dalam metode pedagogis, baik di adaptasi kurikulum dan efektif dalam mendukung pelatihan. ${ }^{40}$ Pelatihan membawa sekelompok orang bersama-sama yang memiliki pengetahuan atau pengalaman peran-manajer dan pemegang peran yang sesuai-dengan fasilitator, biasanya tetapi tidak harus anggota dari departemen sumber daya manusia atau konsultan luar. ${ }^{41}$

Standar nasional pendidikan menunjukan bahwa dalam rangka menjalankan atau melaksanakan proses pendidikan sangat terkait masalah pembiayaan pendidikan, karena dari masing-masing poin dalam standar nasional pendidikan tersebut membutuhkan pembiayaan yang tidak sedikit, sehingga selain menerima batuan pembiayaan pendidikan yang bersifat hibah dari pemerintah pusat yang relatif kurang, pihak pengelola sekolah dituntut untuk berusaha mencari sumber pembiayaan pendidikan lainnya, sehingga permasalahan pembiayaan pendidikan di SMAN 10 Tanjung Jabung Timur dapat terpenuhi dan standar nasional pendidikan dapat terpenuhi.

Selain itu, kepala sekolah juga senantiasa menyiapkan dana cadangan. Dana tersebut diperoleh dari anggaran anggaran sekolah selama satu tahun. Dana cadangan ini akan diperlukan atau digunakan jika sewaktu-waktu anggaran sekolah terlambat cair. Dengan demikian maka seluruh kegiatan, baik yang bersifat pokok (kegiatan belajar mengajar), operasional lainnya maupun kegiatan kesiswaan dapat berjalan dengan baik. Apa yang telah dilakukan oleh kepala sekolah dalam pengelolaan anggaran sekolah yang tepat serta berupaya mencari solusi atas keterlambatan pencairan anggaran sekolah tersebut sesungguhnya adalah merupakan upaya untuk mempertahankan bahkan meningkatkan prestasi sekolah. Dengan tidak terganggunya kegiatan operasional sekolah, belajar mengajar serta kegiatan ekstra lainya maka berarti upaya peningkatan prestasi sekolah tidak terganggu dengan keterlambatan pencairan anggaran sekolah oleh pemerintah. Dengan demikian berarti bahwa prestasi yang telah diperoleh oleh SMAN 10 Tanjung Jabung Timur selama ini dapat dipertahankan dengan baik.

Program anggaran sekolah dalam membantu pembiayaan pendidikan di SMAN 10 Tanjung Jabung Timur cukup maksimal, karena diperkirakan anggaran sekolah telah membantu pembiayaan pendidikan di SMAN 10 Tanjung Jabung Timur. Namun jika dikaitkan dengan harapan pemerintah dan masyarakat, maka upaya yang dilakukan oleh masih tersebut jauh dari harapan, karena semua sember keuangan yang dimiliki sekolah berasal dari anggaran sekolah, padahal harapan pemerintah adalah dengan adanya komite akan meringankan beban pembiayaan pendidikan bagi wali murid atau orang tua siswa. Secara umum pembiayaan pendidikan di bagi menjadi dua bagian, yaitu direct cost atau biaya langsung yang dikeluarkan oleh lembaga atau siswa untuk keperluan pendidikan dan indirect cost atau biaya tidak langsung yang dikeluarkan lembaga atau siswa untuk kebutuhan sehari-hari dan untuk keperluan pendidikan. ${ }^{42}$

${ }^{40}$ International Labour Organization, Handbook of Good Human Resource Practices in the Teaching Profession (Geneva: International Labour Office (ILO), 2012), hal. 242.

${ }^{41}$ Michael Armstrong, A Handbook of Human Resource Management Practice, 10TH Edition (London and Philadelphia: Kogan Page Limited, 2007), hal. 194.

42Ibid., hal. 112. 
Dalam penelitian ini, peneliti mengkhususkan atau mengarahkan penelitian sebatas pembiayaan pendidikan yang langsung dan tidak langsung yang bersifat budgeter atau yang dianggarkan. Artinya bahwa penelitian yang dimaksud dalam penelitian di SMAN 10 Tanjung Jabung Timur ini difokuskan pada masalah pembiayaan yang bersifat anggaran saja, sedangkan biaya-biaya yang dikeluarkan siswa-siswi yang nonbudgeter atau tidak dianggarkan, seperti uang jajan siswa, ongkos atau transportasi dan lain-lain tidak termasuk dalam jenis biaya dalam pembahasan penelitian ini.

Untuk mengetahui masalah pembiayaan pendidikan di SMAN 10 Tanjung Jabung Timur peneliti tidak mengalami kesulitan untuk mendapatkan data, karena pihak-pihak yang terkait atau yang bertanggung jawab masalah keuangan bersedia untuk memperlihatkan dokumentasinya. Kepala sekolah selaku pimpinan tertinggi di SMAN 10 Tanjung Jabung Timur ketika ditanya tentang pembiayaan pendidikan di SMAN 10 Tanjung Jabung Timur dengan singkatnya mengatakan bahwa pembiayaan pendidikan di SMAN 10 Tanjung Jabung Timur belum cukup.

Upaya meningkatkan kualitas pendidikan juga berarti upaya memberikan perhatian dan dukungan seoptimal mungkin kepada pembiayaan pendidikan. Hal ini terlihat dengan telah disetujuinya peningkatan anggaran pendidikan hingga minimal 20\% dari APBN, serta pencanangan program pendidikan gratis seperti yang telah dilakukan oleh Kabupaten Tanjung beberapa waktu yang lalu.

Berdasarkan pengelolaan anggaran sekolah di SMAN 10 Tanjung Jabung Timur, maka mulai dari perencanaan, pelaksanaan, pengawasan serta evaluasi pelaksanaan pembiayaan pendidikan berbasis anggaran sekolah sudah berjalan dengan baik. Dengan kata lain bahwa pelaksanaa pengelolaan anggaran sekolah sudah berjalan secara efektif. Hal ini sebagaimana diungkapkan di atas bahwa kepala sekolah selaku pimpinan tertinggi mampu membuat perencanaan RAPBS yang melibatkan seluruh komponen sekolah melalui rapat kerja (RAKER) sekolah. Dengan demikian kondisi ini juga sejalan dengan program Manajemen Berbasis Sekolah (MBS).

\section{Penutup}

Berdasarkan hasil penelitian yang telah dilakukan pada SMAN 10 Tanjung Jabung Timur, dapat ditarik beberapa kesimpulan bahwa:

1. Kepala sekolah belum mampu mengelola anggaran pendapatan dan belanja pada SMAN 10 Tanjung Jabung Timur karena sumber dan alokasi anggaran masih terbatas. pada pembelanjaannya masih ada permasalahan yaitu: a) Masih kesulitannya pengguna anggaran merincikan kebutuhan anggaran, b) Kemampuan tenaga administrasi dalam mengelola BOS masuh terbatas, c) alokasi anggaran sekolah sebagai sumber pembinaan sekolah masih belum sesuai dengan kebutuhan riil sekolah dan d) Keterbatasan kepala sekolah melakukan pengawasan secara kontinyu.

2. Perencanaan anggaran pendapatan dan belanja yang dilakukan kepala SMAN 10 Tanjung Jabung Timur telah sesuai dengan prosedur dan aturan-aturan yang telah ditetapkan oleh pemerintah. Guna mengefektifkan dan menghindari kesalahan dalam pelaksanaan pembiayaan maka kepala sekolah beserta seluruh guru membuat RAPBS dalam sebuah RAKER sekolah. 
3. Pengelolaan pelaksanaan anggaran pendapatan dan belanja yang dilakukan kepala SMAN 10 Tanjung Jabung Timur disesuaikan dengan RAPBS dan aturan yang telah ditetapkan oleh pemerintah. Pertimbangan dalam pelaksanaan anggaran yaitu dana operasional sekolah, kegiatan kesiswaan serta kesejahteraan khususnya bagi tenaga honorer, pengembangan perpustakaan dan komputer.

4. Penilaian pelaksanaan anggaran pendapatan dan belanja yang dilakukan kepala SMAN 10 Tanjung Jabung Timur sudah berjalan dengan memperbaiki sistim yang ada pad aspek prosedur perincian penggunaan anggaran, pertemuan teknis dan berkelangjutan dalam memberi pelatihan dalam pengelolaan anggaran sekolah, peningkatan penggunaan jika adanya ketelambatan pencairan anggaran sekolah sehingga berpengaruh terhadap kegiatan-kegiatan yang telah direncanakan. Untuk mengantisipasinya, kepala sekolah mencari donatur sementara untuk menutupi pembiayaan selama anggaran sekolah belum cair dan memberikan kewenangan pengawasan kepada pengawas internal yang sudah memahami aturan penggunaan anggaran sekolah.

\section{Bibliografi}

Anonim. Al-Qur'an dan Terjemahnya. Jakarta: Departemen Agama RI. 2007.

Armstrong, Michael. A Handbook of Human Resource Management Practice, 10TH Edition London and Philadelphia: Kogan Page Limited, 2007.

DuBrin, Andrew J. The Complete Ideal's Guides: Leadership. Terj. Tri Wibowo BS, Jakarta: Prenada. 2009.

E. Mulyasa. Menjadi Kepala Sekolah Profesional. Bandung: Remaja Rosdakarya. 2007.

Kurikulum yang Disempurnakan. Bandung: Remaja Rosdakarya. 2007.

. Manajemen Berbasis Sekolah. Bandung: Remaja Rosdakarya. 2007.

Husaini Usman. Manajemen. Jakarta: Bumi Aksara. 2013.

Muhaimin, dkk., Manajemen Pendidikan: Aplikasinya dalam Penyusunan Rencana Pengembangan Sekolah/Madrasah, Jakarta: Kencana, 2011.

Mujamil Qomar. Manajemen Pendidikan Islam. Jakarta: Erlangga. 2007.

Mukhtar. Bimbingan Skripsi, Tesis dan Artikel Ilmiah. Jambi: Sulthan Thaha Press. 2007.

Mukhtar dan Iskandar, Orientasi Baru Supervisi Pendidikan, Jakarta: Referensi, 2013. 
Nanang Fattah. Ekonomi dan Pembiayaan Pendidikan. Bandung: Remaja Rosdakarya. 2007.

Schleicher, Andreas, Ed. Preparing Teachers and Developing School Leaders for The 21st Century - Lessons From Around The World. New York: OECD Publishing, 2012.

Sudarwan Danim. Otonomi Manajemen Sekolah. Bandung: Alfabeta. 2010. Visi Baru Manajemen Sekolah. Jakarta: Bumi Aksara, 2012.

UNICEF. A Human Rights-Based Approach to Education. New York: United Nations Children's Fund. 2007. 